\title{
ANALYSIS OF THE STATUS QUO BEHAVIOURAL CONCEPT DURING THE GLOBAL ECONOMIC CRISIS*
}

\section{Anton Vaskovskyi ${ }^{\mathrm{a}}$}

\begin{abstract}
The objective of this paper is to examine one of the essential behavioural concepts the 'status quo bias' - on the available macroeconomic data. The recent global economic crisis has provided a valuable opportunity for analysing the concept and ensured that relevant and sufficient inputs for such academic research are available. Specifically, to study the 'status quo bias', this paper studies the relation between consumption and income before and after the 2008 economic crisis in a selected country. As such, this study attempts to provide answers to such questions as: How strongly is consumption dependent on income prior to and after the crisis? What are the forces behind consumption during the assessed period - income or existing quality of living? What conclusions can be drawn for public finance from the analysis? The findings indicate that the 'status quo bias' behavioural concept could be confirmed based on the tested macroeconomic data, and possible implications for public finance are presented as well.
\end{abstract}

Keywords: Behavioural economics, status quo, final consumption expenditure of households, disposable income, public finance, real interest rate, real effective exchange rate, co-integration analysis, ADL model

JEL Classification: D12, E71, G40, H31

\section{Introduction}

The 'status quo bias' behavioural concept is based on the assumption that people prefer to maintain their current situation unless there is a substantial incentive to execute any change. Thus, the analysis of the relationship between consumption and income during the crisis is of great relevance and importance for the assessment of this concept

* The paper is processed as an output of the research project "Public finance in the Czech Republic and the EU" registered by the Internal Grant Agency of University of Economics, Prague under the registration number F1/1/2018.

a Anton Vaskovskyi, University of Economics, Prague, Faculty of Finance and Accounting, Prague, Czech Republic.

Email: vaskovskyi@gmail.com 
as it significantly changes economic conditions. The main tested hypothesis is that a decrease of income occurring within the assessed period is significantly different from the decrease in agents' consumption, which is predicted to be lower due to their motivation to maintain the overall quality of living - i.e., the agents attempt to preserve the previous status quo. A co-integration analysis of time series prior to and after the economic crisis will be employed to test the hypothesis. The following indicators will be used: Final consumption expenditure of households, Disposable income, Real interest rate and Real effective exchange rate. The Latvian economy will be chosen for the analysis due to the following reasons:

- $\quad$ an occurrence of a significant decline in the performance of the economy across all strategic sectors, with a consequent impact on the income of the population, and

- a consequent decline in disposable income across the population (including government employees due to statutory interventions).

How strongly is consumption dependent on income prior to and after the economic crisis? What are the forces behind the consumption during the assessed period income or existing quality of living? What conclusions can be drawn for public finance from the analysis? In the article, the author will try to address these questions. Based on an in-depth analysis of the relation between Latvian final consumption and disposable income, real interest rate and real effective exchange rate, the outcome will be drawn based on the available macroeconomic data, either confirming or disproving the behavioural concept. For this purpose, a co-integration analysis will be run, and an ADL model will be constructed to investigate the short- and long-term relations between the aforementioned financial data series. The results of the empirical analysis of the population data (as macroeconomic data represent the whole country) will be compared to the findings of behavioural economy in order to come up with appropriate interpretations. Finally, a summary of the key findings and conclusions will be presented.

\section{Theoretical Framework}

The status quo bias represents an idea that people tend to maintain their original condition / choice as they expect that an increase of utility in the case of a change will not be significant enough compared to the utility resulting from maintaining the current status and preserving the resources needed to make the change. This phenomenon has evolved from risk aversion as one of the fundamental behavioural concepts. Samuelson and Zeckhouser (1988) verified the finding during an experiment, in which one of the groups of participants (the control group) received the following assignment "You are a serious reader of the financial pages but until recently have had few funds to invest. That is when 
you inherited a large sum of money from your great uncle. You are considering different portfolios." The choices were:

- a medium-risk company,

- a high-risk company,

- a treasury bill, or

- government bonds.

Other groups of participants were presented with a similar assignment with a small modification - in the inheritance proceedings, they received one of the investment instruments at a given value instead of the large sum of money as free funds. The authors were able to determine the investment strategy based on the control group without affecting the possession of investment instruments. The results have shown that for alternative groups, investment instruments already held are preferred to the control group's investment selection. The significance of this phenomenon increases as the number of alternatives increases (Kahneman et al., 1991, pp. 197-199). Those findings were later confirmed by Kempf and Ruenzi (2005), who examined the status quo bias on mutual fund markets. According to their study, the agents tend to repeat their investment choices by selecting the assets chosen previously even if such a decision is no longer optimal.

Strong evidence of status quo bias was also concluded within a study of organ donation and the opt-in vs. opt-out option. In this case, the default option is perceived to be the dominant factor in the agents' decision process (Johnson and Goldstein, 2004). The aforementioned experiments are consistent with the idea of the status quo behavioural concept.

The recent economic crisis provides a valuable opportunity to assess the aforementioned behavioural concept on the macroeconomic level of a selected country. The macroeconomic data employed during the analysis reflect the whole population in contrast to an organised experiment, which only represents a limited sample. To be able to meet the objective, it is necessary to select a country that has had a tangible decline in income across the entire population. This condition can be met based on two possible scenarios:

1. a significant decline in the performance of the economy across all strategic sectors, with a consequent impact on the income of the population, or

2. a direct decline in wages and salaries across the population.

As is presented in the following text, Latvia was selected for the analysis, as it is believed to have met both of those conditions. 


\section{Country Selection}

A significant decline in the performance of the economy is met by countries that have suffered an extensive negative impact of the economic crisis. A common feature of those countries is a strong dependency on both international trade and international banking.

Latvian dependency on international trade can be observed through the current account balance, which in the examined time period reached a deficit of $13 \%$ in 2014 and even exceeded the 20\% threshold in the pre-crisis years 2006 and 2007 (Spurná, 2013, p. 48). In terms of the banking sector, the country heavily depended on neighbouring countries such as the Nordic companies, which owned the majority of financial institutions operating in Latvia (Purfield and Rosenberg, 2010, p. 4). As a result, the Latvian economy experienced a significant decline of $21 \%$ in the nominal gross domestic product per capita between 2008 and 2009.

The Forbes magazine has recently published a list of countries hit hardest by the global economic downturn at the end of the first decade of the new millennium. The countries were ranked based on the development of the three key macroeconomic indicators:

1. gross domestic product,

2. inflation, and

3. change in purchasing power.

Table 1: The world's hardest-hit economies according to Forbes

\begin{tabular}{l|l|c|c|c}
\hline $\mathbf{R a n k}$ & Country & GDP decline (\%) & Inflation (\%) & Neg. change in purchasing power (\%) \\
\hline $\mathbf{1}$ & Latvia & 17.8 & 5.0 & 13.8 \\
\hline $\mathbf{2}$ & Seychelles & 7.2 & 31.4 & 6.0 \\
\hline $\mathbf{3}$ & Estonia & 14.2 & 3.3 & 11.3 \\
\hline $\mathbf{4}$ & Iceland & 10.5 & 8.5 & 10.0 \\
\hline $\mathbf{5}$ & Ireland & 12.8 & 1.2 & 11.9 \\
\hline $\mathbf{6}$ & Venezuela & 2.0 & 36.8 & 4.0 \\
\hline $\mathbf{7}$ & Singapore & 9.6 & 2.5 & 10.6 \\
\hline $\mathbf{8}$ & Lithuania & 10.7 & 5.6 & 5.2 \\
\hline $\mathbf{9}$ & Ukraine & 5.1 & 17.3 & 5.0 \\
\hline $\mathbf{1 0}$ & Jamaica & 4.0 & 13.5 & 2.0 \\
\hline
\end{tabular}

Source: Forbes, 2009 
Based on the presented findings, Latvia seems to be an optimal selection regarding the first condition relating a tangible decline in the performance of the economy across all strategic sectors.

The original Latvian currency was linked to the euro at a fixed exchange rate from 2005 and therefore, a currency devaluation was initially envisaged. Nevertheless, given the considerable volume of euro-denominated loans, such a decision would greatly reduce the wealth of the population and increase the amount of outstanding loans and insolvencies with a negative impact on the entire financial and, eventually, the economic systems. Devaluing the currency or switching to a flexible rate could also be perceived as a monetary policy failure. Due to such expected impacts, Latvia opted for an internal devaluation through fiscal policy with the following objectives:

- reduction of public expenditures to restore the sustainability of the public budget,

- meeting of the Maastricht criteria, and

- maintaining of the current fixed exchange rate in order to adopt the euro at the earliest possible date.

One of the measures to reduce public expenditures and to increase competitiveness was the correction of nominal wages. Specifically, the intention was to reduce production costs by adjusting the nominal wages in state administration with a subsequent impact on the public sector expenditures (Purfield and Rosenberg, 2010, pp. 12-19). In December 2008, Latvia approved an emergency plan, including extensive wage cuts linked to the state budget. The related law entered into force on 1 January 2009, with each public institution having the option to choose whether to reduce wages, the number of employees or opt for a combination of both to meet the established budget (Latvian Government, 2008). A different approach was chosen for the flat reduction of wages for civil servants (Official Journal of Latvia, 2010, p. 11):

- $15 \%$ salary reduction for salaries of up to 300 Latvian lats, and

- $20 \%$ salary reduction for salaries exceeding 300 Latvian lats.

In the year-on-year comparison of 2008 and 2009, an average decrease of $17 \%$ in the salary for public sector employees can be observed in Figure 1. 
Figure 1: Comparison of average monthly earnings of employees of state institutions in Latvia in 2008 and 2009 (EUR)

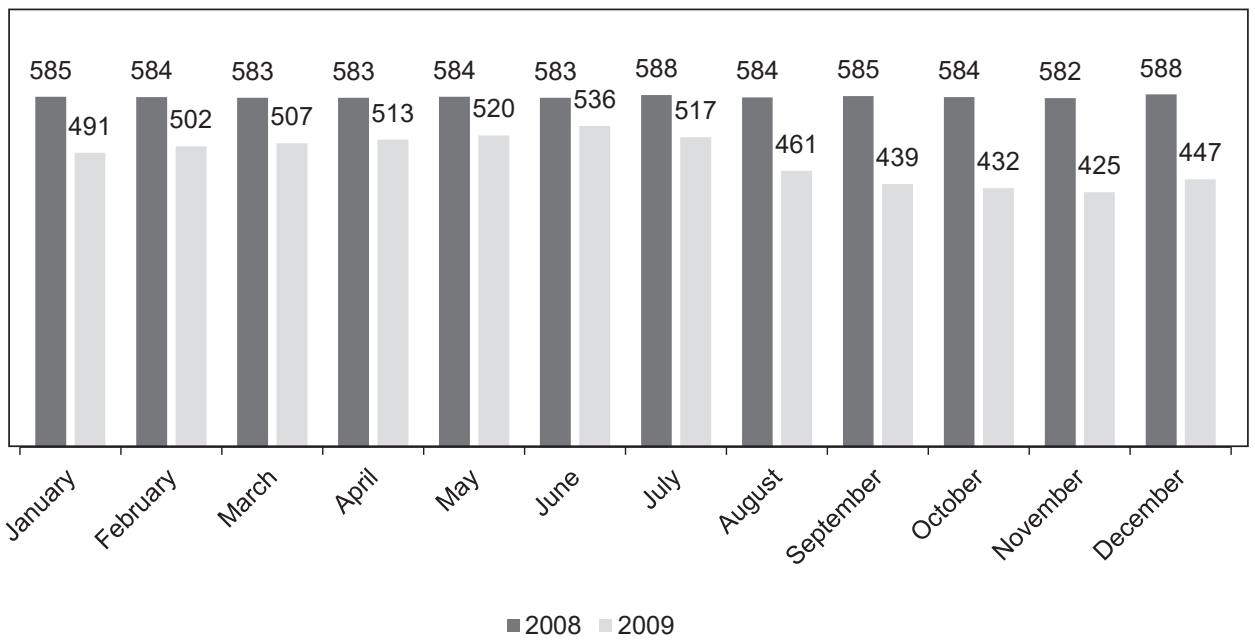

Source: Central Statistical Bureau of Latvia (2015)

The ongoing economic crisis and measures taken by the Government of Latvia consequently negatively affected the unemployment rate, which more than tripled between 2007 and 2010 (Figure 2).

Figure 2: Unemployment rate in Latvia between 2007 and 2010

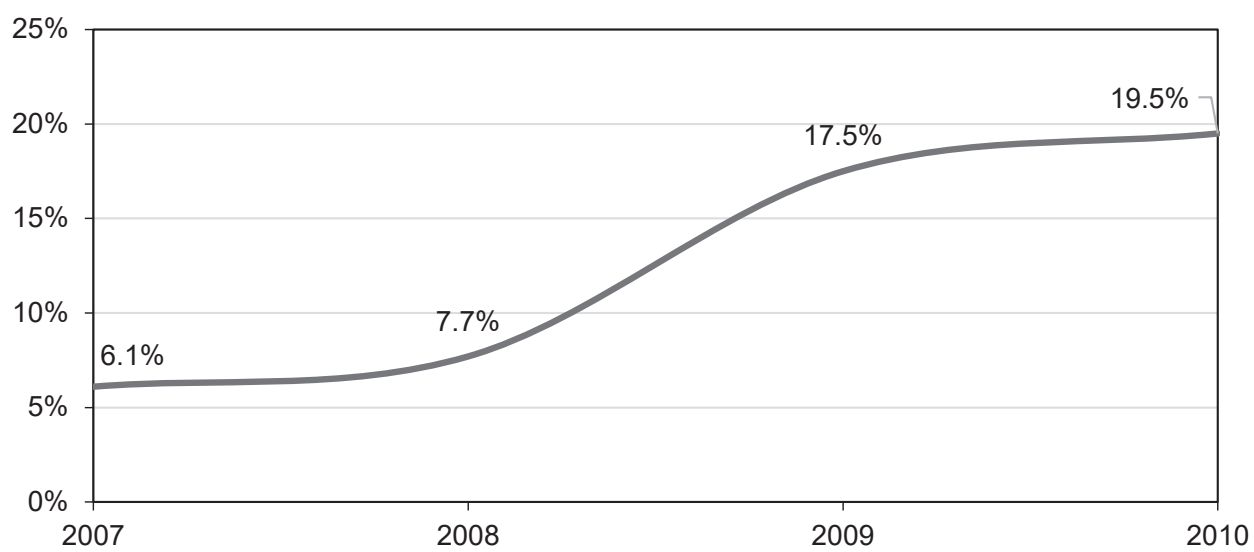

Source: Central Statistical Bureau of Latvia (2015) 
A sharp rise in the unemployment rate and the overall reduction of wages in the public sector had a spill-over effect on the private sector wages (Figure 3), starting from June 2009 onwards. The abrupt decline is evident when comparing the years 2009 and 2010. According to the official available data, the reduction in the private sector wages was still less pronounced as compared to the public one. However, it is necessary to take into account the possibility of additional income the employees within the private sector can achieve from the "shadow" economy in contrast to those within the public sector.

Figure 3: Comparison of average monthly earnings of employees in the private sector in Latvia in 2009 and 2010 (EUR)

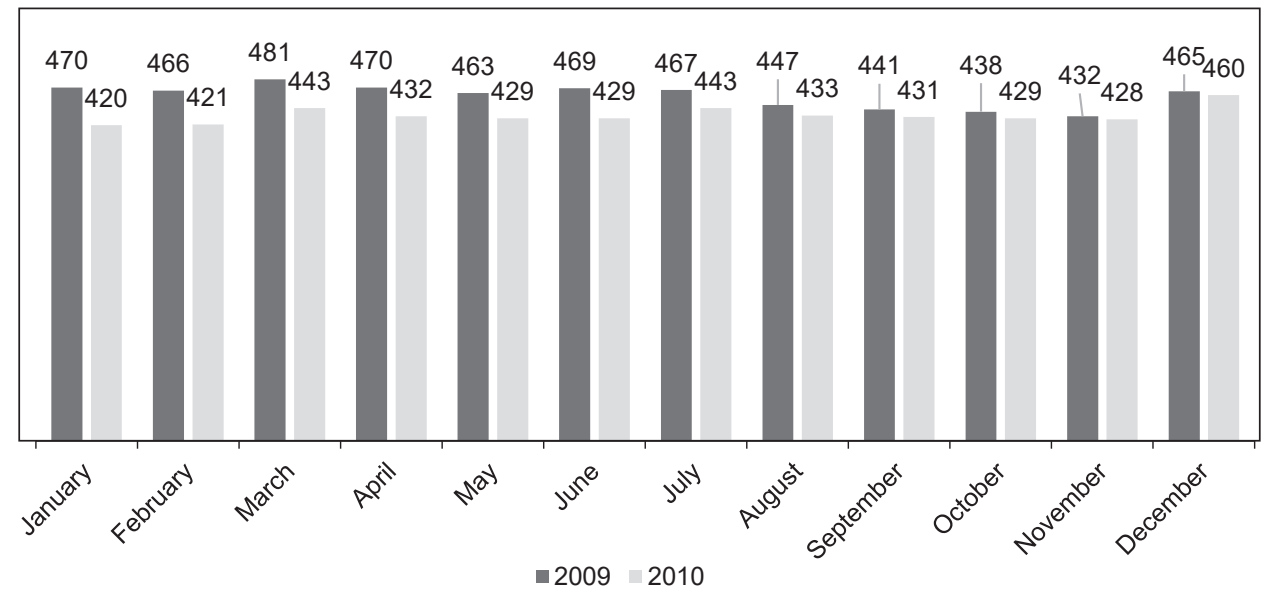

Source: Central Statistical Bureau of Latvia (2015)

Based on these findings, this study considers that Latvia does fulfil the second aforementioned condition for country selection for the purpose of this analysis.

\section{Co-integration Analysis}

To empirically elaborate on 'status quo bias', this study begins its analysis by testing the relationship between consumption and income by employing standard econometric tools. The consumption is represented by the time series Final consumption expenditure of households (hereinafter, "Consumption"), which is defined by OECD as "the amount of final consumption expenditure made by resident households to meet their everyday needs, such as: food, clothing, housing (rent), energy, transport, durable goods (notably, cars), health costs, leisure, and miscellaneous services" (OECD, 2018). The population's 
income will be represented by the time series Disposable income (hereinafter, "Income"), which is defined by OECD as "the sum of wages and salaries, mixed income, net property income, net current transfers and social benefits other than social transfers in kind, less taxes on income and wealth and social security contributions paid by employees, the selfemployed and the unemployed". Since the consumption is expected to be driven by wealth rather than the disposable income, the study also includes other determinants such as the interest rate and the exchange rate in the estimations.

The interest rate is represented by the time series Real interest rate (hereinafter, "Interest rate") calculated as the short-term interest rate adjusted for inflation. Short-term interest rate is used due to its availability in the required period and frequency of the data. OECD (2019) defines short-term interest rates as "rates at which short-term borrowings are effected between financial institutions or the rate at which a short-term government paper is issued or traded in the market. Short-term interest rates are generally averages of daily rates, measured as a percentage“. Inflation is represented by the consumer price index (CPI), which is used for the same reason as the aforementioned short-term interest rate. The exchange rate is represented by the time series Real effective exchange rate (hereinafter, "Exchange rate"), which is defined by OECD (2019) as "summary measure of the changes in the exchange rates of a country vis-à-vis its trading partners". The study employs country-level variables, as data per capita were not available at a required frequency for all the datasets. The variables are presented in millions of EUR (Consumption, Income), percentages (Interest rate) or indices (Exchange rate). Despite the existence of such important determinants of consumption as financial wealth (e.g., investments, heritage, real estate price level change) and for the sake of simplicity of the analysis and straightforward model interpretation, the study assumes that the disposable income is the only source of the population's income.

The empirical estimations are implemented in two steps. First, the study analyses the dependency of Consumption $\left(C O N_{-} B C\right)$ on Income ( $\left.I N C_{-} B C\right)$, Interest rate $\left(R I R \_B C\right)$ and Exchange rate $\left(R_{E E R} B C\right)$ before the crisis. This part of the analysis is based on quarterly data for the period I/1999-II/2008, which covers a period of available data prior to the decline in consumption. Secondly, the paper examines the relationship of time series after the crisis, which is based on quarterly data for the period III/2008-IV/2014 (Consumption " $C O N_{-} A C$ ", Income "INC_AC", Interest rate " $R I R \_A C$ ", Exchange rate "REER_AC"). The 2014 cut-off point was selected based on the following arguments:

- The discrepancy in the analysed relationship cannot persist for an infinitely long period of time. If the hypothesis is correct and thus even after the decline in Income, consumers tend to preserve their status quo (i.e., overall quality of living), they must reduce savings or draw from their previously accumulated finite resources. 
- Consumption exceeded its pre-crisis values in 2014, which could be interpreted as the end of the crisis period.

As shown in Figure 4, Consumption is smoothened and rather stable in comparison with Income, which supports the hypothesis that a population tends to preserve its quality of living despite shocks on the income side.

\section{Figure 4: Seasonally adjusted income (million EUR), consumption (million EUR), interest rate $(\%)$ and exchange rate (index $2010=100$ )}

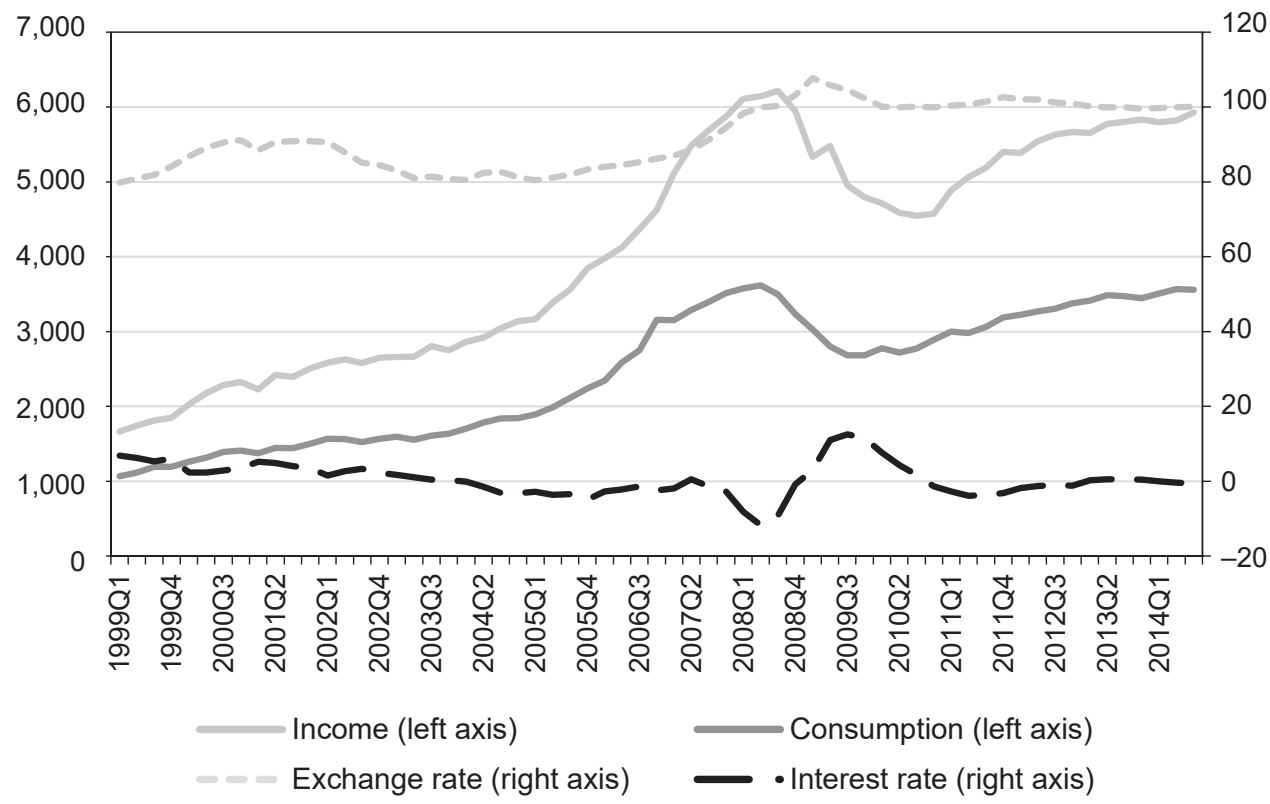

Source: Eurostat (2018)

For the analysis of the difference between the actual consumption and the hypothetical consumption based on the historical data, a counterfactual simulation is employed.

As can be seen from Figure 5, the hypothetical path of the consumption, using the model estimated prior to the devaluation, suggests that the population's consumption should have been lower than it actually was based on the development of macroeconomic variables used in the model. Such development supports the hypothesis presented in this paper.

While the initial intention was to collect the data directly from the primary source the Central Statistical Bureau of Latvia, the requested data were not available for the required period. Therefore, the statistical data were drawn either from Eurostat (Consumption, 
Income), the Statistical Office of the European Union according to the recommendation made in the "Overview of Selected Macroeconomic Indicators of European Union Countries and Other World Centres and Analysis of "Statistical" Servers" (2011) or from the OECD (Short-term interest rate, CPI, Exchange rate).

\section{Figure 5: Counterfactual simulation based on normalized seasonally adjusted data}

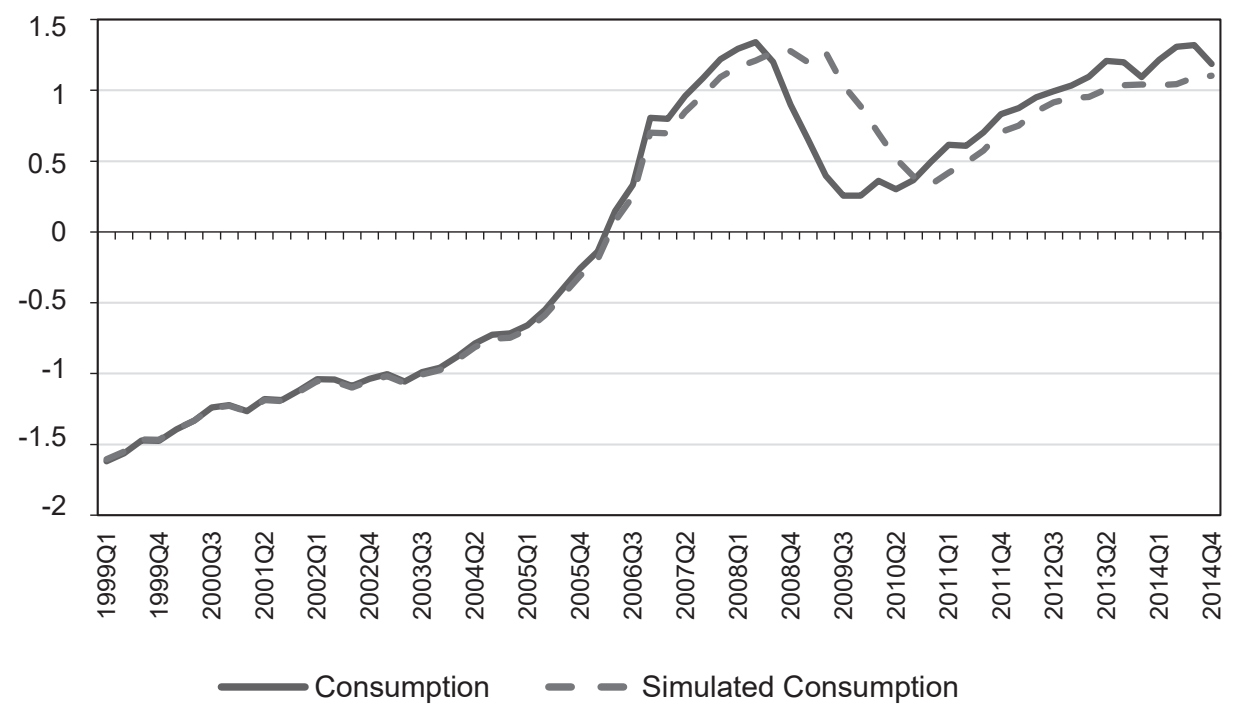

Source: own calculations

For a seasonal adjustment of the data, the X12ARIMA method was employed (U.S. Census Bureau, 2004). According to the results of the Augmented Dickey-Fuller tests (hereinafter, "ADF tests") (Dickey and Fuller, 1979) in Table 2 for the analysis before the crisis, the time series are non-stationary and integrated to the order 1, i.e., I(1). For the original time series, the unit root hypothesis was tested using drift and linear trend as well as using only drift; the ADF tests with a constant were used for the differenced time series. Lag length was chosen automatically based on the Schwarz Info Criterion (maximum lags $=9$ ).

The results of the ADF tests for the time series after the crisis are presented in Table 3. The deterministic part of the unit root hypothesis testing was selected based on a visual analysis of the time series; Consumption and Income were tested using drift and linear trend while only drift was chosen for testing Interest rate and Exchange rate. Lag length was chosen automatically based on the Schwarz Info Criterion (maximum lags $=5$ ). 
The author's assumption that the time series are non-stationary and integrated to the order 1 , i.e., I(1) was confirmed for Consumption and Exchange rate.

Table 2: Unit root test of seasonal adjusted time series and their first differences before crisis

\begin{tabular}{|c|c|c|c|c|}
\hline \multirow{2}{*}{$1 / 1999-I I / 2008$} & \multicolumn{4}{|c|}{ Seasonal adjusted time series } \\
\hline & $\boldsymbol{t}_{\text {adf }- \text { trend, constant }}$ & Prob. & $\boldsymbol{t}_{\text {adf - constant }}$ & Prob. \\
\hline$C O N \_B C$ & -0.2325 & 0.9898 & 2.4698 & 1.0000 \\
\hline$I N C_{-} B C$ & 0.5089 & 0.9989 & 3.5304 & 1.0000 \\
\hline$R I R_{-} B C$ & -2.3229 & 0.4116 & 0.2513 & 0.9723 \\
\hline$R E E R \_B C$ & -0.8901 & 0.9463 & -0.8968 & 0.7778 \\
\hline \multirow{2}{*}{$1 / 1999-I I / 2008$} & \multicolumn{4}{|c|}{ First differences } \\
\hline & \multicolumn{2}{|c|}{$t_{\text {adf - constant }}$} & \multicolumn{2}{|c|}{ Prob. } \\
\hline$C O N \_B C$ & \multicolumn{2}{|c|}{-4.5597} & \multicolumn{2}{|c|}{0.0008} \\
\hline INC_BC & \multicolumn{2}{|c|}{-3.5316} & \multicolumn{2}{|c|}{0.0127} \\
\hline$R I R_{-} B C$ & \multicolumn{2}{|c|}{-4.3663} & \multicolumn{2}{|c|}{0.0014} \\
\hline REER_BC & \multicolumn{2}{|c|}{-2.9883} & \multicolumn{2}{|c|}{0.0456} \\
\hline
\end{tabular}

Source: own calculations

Information provided in Table 3 suggests that the $\mathrm{ADF}_{c, t}$ test rejects that $I N C \_A C$ is $\mathrm{I}(1)$ type but $\mathrm{ADF}_{c}$ does not reject it, which means that it can be consid- ered stationary around the linear trend (trend-stationary), so it is still non-stationary, in fact. Both $\mathrm{ADF}_{c, t}$ and $\mathrm{ADF}_{c}$ tests reject that RIR_AC is I(1) type; it follows that this time series can be considered $\mathrm{I}(0)$. However, both $\mathrm{PP}_{c, t}$ and $\mathrm{PP}_{c}$ tests do not reject that RIR_AC is I(1) type. If the development of this time series plotted in Figure 6 is taken into account, it can be considered I(1). 
Table 3: Unit root test of seasonal adjusted time series and their first differences after crisis

\begin{tabular}{|c|c|c|c|c|}
\hline \multirow{2}{*}{ III/2008 - IV/2014 } & \multicolumn{4}{|c|}{ Seasonal adjusted time series } \\
\hline & $\boldsymbol{t}_{\text {adf }- \text { trend, constant }}$ & Prob. & $\boldsymbol{t}_{\text {adf - constant }}$ & Prob. \\
\hline$C O N \_A C$ & -1.5082 & 0.7920 & -1.5404 & 0.4965 \\
\hline INC_AC & -3.6147 & 0.0489 & -1.2181 & 0.6493 \\
\hline$R I R \_A C$ & -5.2636 & 0.0022 & -5.7077 & 0.0002 \\
\hline REER_AC & -3.4540 & 0.0774 & -2.8376 & 0.0680 \\
\hline \multirow{2}{*}{ III/2008 - IV/2014 } & \multicolumn{4}{|c|}{ First differences } \\
\hline & \multicolumn{2}{|c|}{$\boldsymbol{t}_{\text {adf - constant }}$} & \multicolumn{2}{|c|}{ Prob. } \\
\hline$C O N \_A C$ & \multicolumn{2}{|c|}{-4.4802} & \multicolumn{2}{|c|}{0.0098} \\
\hline INC_AC & \multicolumn{2}{|c|}{-4.4914} & \multicolumn{2}{|c|}{0.0081} \\
\hline$R I R \_A C$ & \multicolumn{2}{|c|}{-3.4208} & \multicolumn{2}{|c|}{0.0202} \\
\hline REER_AC & \multicolumn{2}{|c|}{-3.6532} & \multicolumn{2}{|c|}{0.0121} \\
\hline
\end{tabular}

Source: own calculations

Figure 6: Seasonally adjusted income (million EUR) and interest rate (\%) after crisis

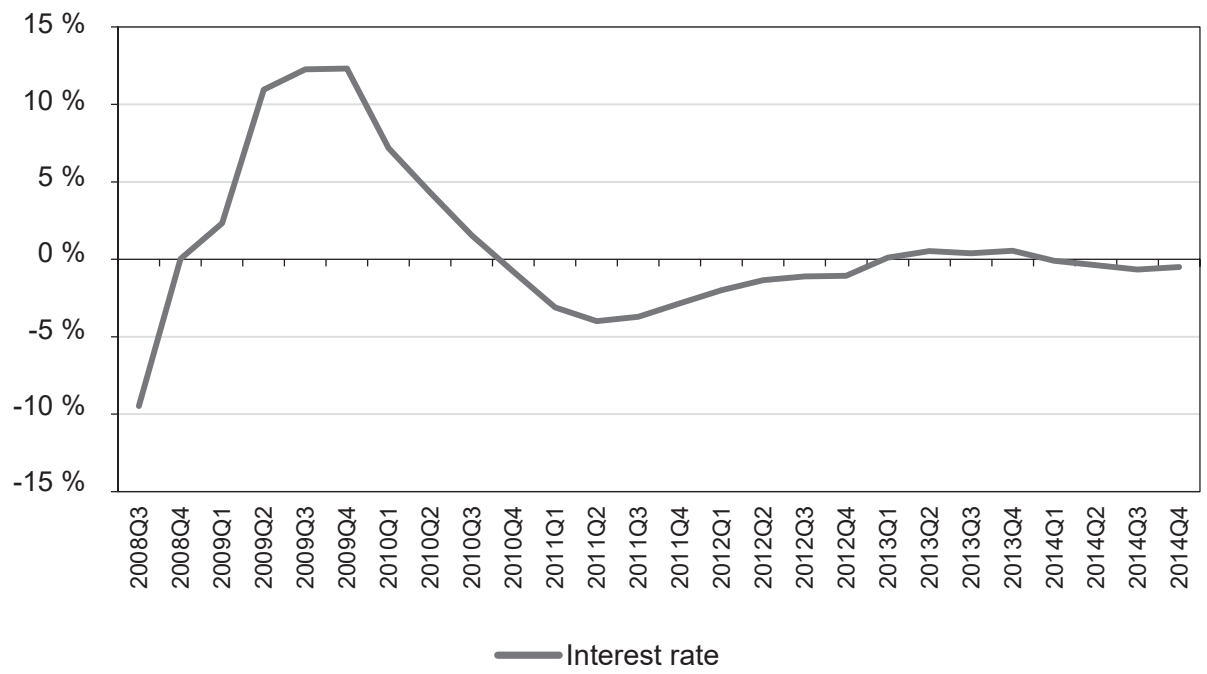

Source: Eurostat (2018) and own calculations 
Based on Figure 6, the stationarity of the time series cannot be visually detected. The study further addresses the unit root analysis using the Phillips-Perron test as an alternative to the ADF test (Table 4).

Table 4: Unit root test of seasonal adjusted income and interest rate and their first differences after crisis

\begin{tabular}{l|c|c|c|c}
\hline \multirow{2}{*}{ III/2008-IV/2014 } & \multicolumn{4}{|c}{ Seasonal adjusted time series } \\
\cline { 2 - 5 } & $\boldsymbol{t}_{\mathrm{pp}-\text { trend, constant }}$ & Prob. & $\boldsymbol{t}_{\mathrm{pp}-\text { constant }}$ & Prob. \\
\hline $\boldsymbol{R} I \boldsymbol{R} \_\boldsymbol{A C}$ & -3.1582 & 0.1154 & -2.6827 & 0.0910 \\
\hline \multirow{2}{*}{ III/2008-IV/2014 } & \multicolumn{3}{|c}{ First difference } \\
\cline { 2 - 5 } & \multicolumn{3}{|c|}{$\boldsymbol{t}_{\mathrm{pp} \text { - constant }}$} & \multicolumn{2}{c}{ Prob. } \\
\hline RIR_AC & \multicolumn{2}{|c|}{-3.4675} & \multicolumn{2}{|c}{0183} \\
\hline
\end{tabular}

Source: own calculations

In addition to the results for the alternative unit root test for Interest rate, there is a strong economic rationale to take the time series into consideration for the analysis.

The time series should be co-integrated; otherwise, the results of the assessment may be impacted by so-called spurious regression (Granger and Newbold, 1974). Therefore, the Engle-Granger test for co-integration (Engle and Granger, 1987) is applied, which is based on the following regression model:

$$
Y_{t}=\beta X_{t}+a_{t}
$$

The analysed time series are co-integrated if the residuals of this model are stationary. The ADF test with no deterministic term is used for the testing.

\subsection{Interrelation of the Latvian consumption and income before crisis}

To analyse the relationship before the impact of the economic crisis, the study examines seasonally adjusted available data until the first decline in one of the indicators (i.e., the third quarter of 2008). Visual inspection of Figure 7 supports the hypothesis of the long-term relationship between the analysed variables. The presented data were normalized using Excel functions, both the arithmetic mean and standard deviation of the data. 


\section{Figure 7: Normalized data of seasonally adjusted income and consumption before crisis (I/1995 - II/2008)}

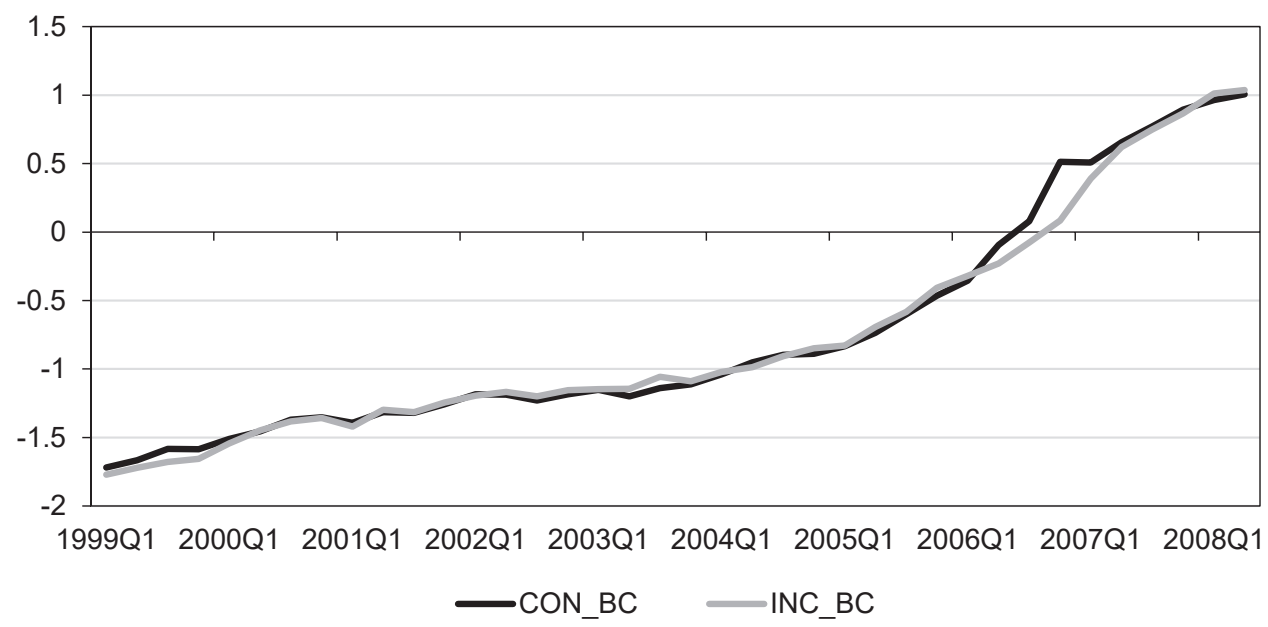

Source: Eurostat (2019), own calculations

A significant shift in the trend of the variables is induced by Latvia's entry into the European Union on 1 May 2004. Additionally, the Bank of Latvia decided to keep a pegged rate regime of the lats to the euro due to its planned entry into the European Monetary Union, thereby further limiting the possibility of using exchange rate interventions and monetary policy instruments. Therefore, the conversion to the euro area was carried out through the price channel and this has catalysed the rise in nominal wages and prices (Cupalová, 2009). As the economy was overheating in the period shortly before the crisis, the increase in Income noticeably exceeded Consumption. This aspect could be explained by the following conventional theories:

- the population's expectation that the rapidly rising incomes are caused by the phase of the business cycle and cannot last for an infinitely long time (Izák, 2011); and / or

- Friedman's Theory of Consumption (1957): the population unconsciously divided current income into the remaining consumption cycle (i.e., the rest of the subjects' lifetime), and thus the current consumption grew relatively less than the income.

As can be seen from Table 3, Table 4 and Figure 6, all the time series are non-stationary of the order 1, i.e., I(1); therefore, the author applied the ADF test without drift or linear trend to residuals of a statistic regression model before crisis (RESID_BC) to determine the basis of the relationship of the time series. Lag length was chosen automatically based on the Schwarz Info Criterion (maximum lags $=9$ ). The static regression model is specified in the Appendix . 
Table 5: Unit root test of statistic regression model residuals before crisis

\begin{tabular}{l|c|c}
\hline \multicolumn{3}{c}{ Null hypothesis: Residuals have a unit root } \\
\hline Dependent & $\boldsymbol{t}_{\text {adf }}$ & Prob. \\
\hline RESID_BC & -3.8815 & 0.0003 \\
\hline
\end{tabular}

Source: own calculations

According to the results shown in Table 5, the study eliminates the possibility of spurious regression as the residuals are stationary. Afterwards, the ADL model is employed to address the problem of autocorrelation (Table 6) and three dummy variables are applied to eliminate the possible impact of certain events occurring during the assessed time period:

- D1 (I/2007): Presidential election campaign,

- D2 (IV/2006): Parliamentary election,

- $\quad$ D3 (II/2006): Men's world ice hockey championships 2006 held in Latvia.

Table 6: ADL model I - before crisis

\begin{tabular}{|c|c|c|c|c|}
\hline \multicolumn{5}{|c|}{ Dependent variable: $C O N \_B C$} \\
\hline Variable & Coefficient & Std. error & t-Statistic & Prob. \\
\hline$C O N \_B C(-1)$ & 0.8687 & 0.1130 & 7.6883 & 0.0000 \\
\hline$I N C_{-} B C$ & 0.3110 & 0.0670 & 4.6412 & 0.0001 \\
\hline$I N C_{-} B C(-1)$ & 0.2466 & 0.0683 & -3.6119 & 0.0013 \\
\hline$R E E R \_B C$ & 8.9301 & 3.5865 & 2.4899 & 0.0195 \\
\hline$R E E R \_B C(-1)$ & -8.0814 & 3.4515 & -2.3414 & 0.0271 \\
\hline$R I R \_B C(-3)$ & -7.7506 & 2.3497 & -3.2986 & 0.0028 \\
\hline$D 1(1 / 2007)$ & -138.2823 & 46.8973 & -2.9486 & 0.0067 \\
\hline D2 (IV/2006) & 306.2323 & 28.3837 & 10.7890 & 0.0000 \\
\hline D3 (II/2006) & 150.4124 & 24.9718 & 4.6412 & 0.0000 \\
\hline Adj. $R^{2}$ & \multicolumn{2}{|c|}{0.9991} & Durbin-Watson & 2.2211 \\
\hline \multicolumn{3}{|c|}{ Diagnostic tests } & Statistics & Prob. \\
\hline \multicolumn{3}{|c|}{ Breusch-Godfrey Serial Correlation LM Test } & 0.3692 & 0.6951 \\
\hline \multicolumn{3}{|c|}{ Jarque-Bera Test } & 0.4972 & 0.7799 \\
\hline \multicolumn{3}{|l|}{ ARCH(1) Test } & 1.6717 & 0.2053 \\
\hline \multicolumn{3}{|l|}{ Q-stat(4) } & $>0.5113$ & $>0.389$ \\
\hline
\end{tabular}

Source: own calculations 
A portmanteau test was applied for autocorrelation testing of the model; according to the results, residuals of the time series are not significantly different from zero (lag length $=28$ ).

The final ADL model (Table 6) can be written as follows:

$$
\begin{aligned}
\overline{C O N_{-} B C_{t}} & =0.87 C O N_{-} B C_{t-1}+0.31 I N C_{-} B C_{t}-0.25 I N C_{-} B C_{t-1}+ \\
& +8.93 R E E R_{-} B C_{t}-8.08 R E E R_{-} B C_{t-1}- \\
& -7.75 R I R_{-} B C_{t-3}-138.28 D 1_{t}+306.23 D 2_{t}+150.41 D 3_{t}
\end{aligned}
$$

It can be seen that Latvian Consumption depends on its lagged value in the time $t-1$, on Latvian Income in the time $t$ and $t-1$, on Exchange rate in the time $t$ and $t-1$ and on Interest rate in the time $t-3$. Further, the author has rewritten the model in the form of an EC model:

$$
\begin{aligned}
\Delta \overline{C O N_{-} B C_{t}} & =0.1313 \Delta C O N_{-} B C_{t-1}+0.1313 \Delta C O N_{-} B C_{t-2}+0.3110 \Delta I N C_{-} B C_{t}+ \\
& +0.3110 \Delta I N C_{-} B C_{t-1}+0.3110 \Delta I N C_{-} B C_{t-2}+8.9301 \Delta R E E R_{-} B C_{t}+ \\
& +8.9301 \Delta R E E R_{-} B C_{t-1}+8.9301 \Delta R E E R_{-} B C_{t-2}+ \\
& +0.1313\left(C O N_{B C t-3}-0.4905 I N C_{B C t-3}-129.6306 R E E R_{t-3}+\right. \\
& \left.+59.0297 R I R_{-} B C_{t-3}\right)
\end{aligned}
$$

The EC model shows the speed of the system's convergence to reach its long-term equilibrium in the case of a deviation of the current state from its long-run relationship as measured by the parameter $\gamma(0.1313)$ and the long-term relationship between the variables as measured by the multipliers $\beta(0.4905), \delta(129.6306)$ and $\phi(59.0297)$. The long-term relationship is expressed by the term $\mathrm{EC}$, which is given by the equation:

$$
E C_{t}=C O N_{-} B C_{t}-0.4905 I N C_{-} B C_{t}-129.6306 R E E R_{-} B C_{t}+59.0297 R I R_{-} B C_{t}
$$

The conclusion is that Latvian Consumption is indeed dependent on Income. A diagnostic check of the model indicates that the unsystematic part of the model is white noise (Breusch and Godfrey, 1986; Jarque and Bera, 1980; Darnell, 1994).

\subsection{Interrelation of the Latvian consumption and income after crisis}

To evaluate the relationship after the impact of the economic crisis, the study examines seasonally adjusted data for the period III/2008-IV/2014. Based on visual grafical analysis (Figure 8), a loss of interdependence is expected of selected macroeconomic variables 
in Latvia in the period after the economic crisis and, consequently, Consumption exceeds Income during the remaining assessed period.

Figure 8: Normalized data of seasonally adjusted income and consumption after crisis (III/2008 - IV/2014)

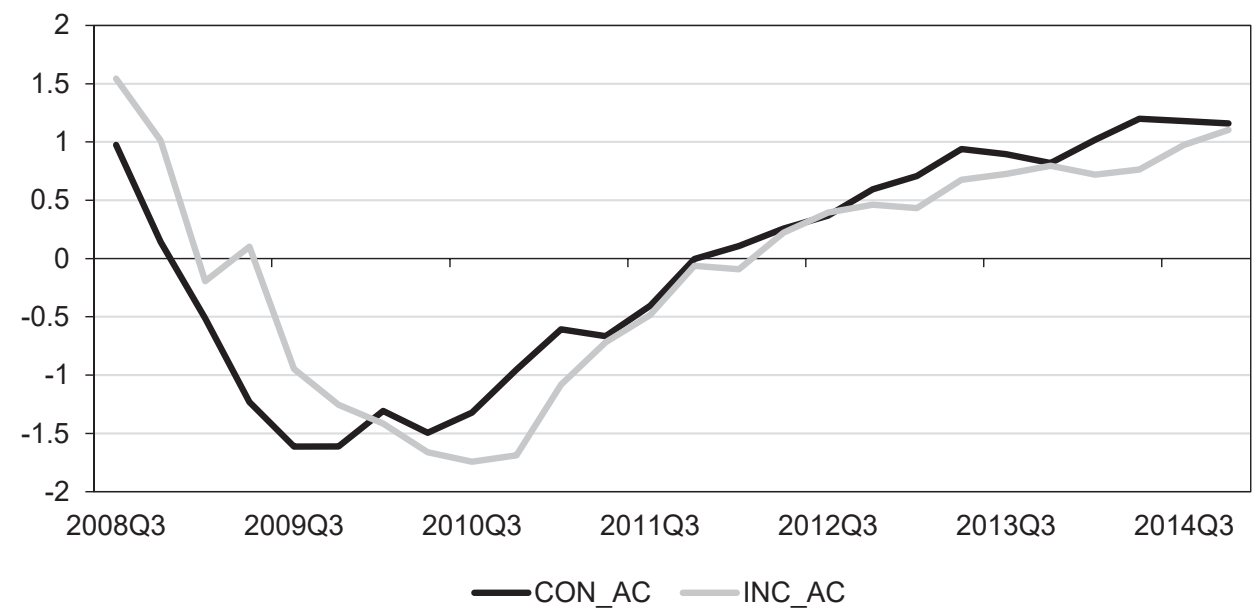

Source: Eurostat (2019), own calculations

Figure 8 shows that the impact of the economic crisis was more significant in the case of Income compared to Consumption. Latvian population did not fully adapt their daily consumption to a drastic decline in income, which in this case may indicate an effort to maintain, or minimize the decline in, the past welfare and lifestyle. Such conduct may indicate use of previously accumulated savings or reduction of savings, ceteris paribus. This would support the idea of the status quo bias concept.

The study follows the methodology from the previous section in order to analyse the relationship of the time series after the economic crisis. As can be seen from Table 3, Table 4 and Figure 8, all the time series are non-stationary of the order 1, i.e., I(1). Therefore, the study runs an ADF tests (without drift or linear trend) of the statistic regression model residuals to evaluate the nature of the relationship between the selected time series (Table 7). Lag length was chosen automatically based on the Schwarz Info Criterion (maximum lags $=5$ ). The static regression model is specified in the Appendix. 
Table 7: Unit root test of statistic regression model residuals after crisis

\begin{tabular}{l|c|c}
\hline \multicolumn{3}{c}{ Null hypothesis: Residuals have a unit root } \\
\hline Dependent & $\mathbf{t}_{\text {adf }}$ & Prob. \\
\hline RESID_AC & -4.8456 & 0.0000 \\
\hline
\end{tabular}

Source: own calculations

The estimated model for the analysis is presented in Table 8. For the period just after the crisis, a dummy variable was applied to eliminate the specific nature of the time series, i.e., the steep negative trend for the period II/2008-III/2009.

Table 8: ADL model II - after crisis

\begin{tabular}{l|c|c|c|c}
\hline \multicolumn{1}{c}{ Variable } & Coefficient & Std.error & t-Statistic & Prob. \\
\hline CON_AC(-1) & 0.5222 & 0.1503 & 3.4741 & 0.0023 \\
\hline CON_AC(-4) & 0.4127 & 0.1594 & 2.5897 & 0.0171 \\
\hline RIR_AC & -23.9281 & 7.2474 & -3.3016 & 0.0034 \\
\hline REER_AC(-2) & 0.4127 & 0.1594 & 2.5897 & 0.0171 \\
\hline D4 (II/2008-III/2009) & -299.3867 & 47.7360 & -6.2717 & 0.0000 \\
\hline Adj. $\boldsymbol{R}^{2}$ & \multicolumn{1}{|c|}{0.9699} & Durbin-Watson & 1.8873 \\
\hline Diagnostic tests & & Statistics & Prob. \\
\hline Breusch-Godfrey Serial Correlation LM Test & 0.5323 & 0.5958 \\
\hline Jarque-Bera Test & & 0.4341 & 0.8788 & $>0.294$ \\
\hline ARCH(1) Test & & & 0.0082 & 0.3583 \\
\hline Q-stat(4) & & &
\end{tabular}

Source: own calculations

A portmanteau test was applied for autocorrelation testing of the model; according to the results, residuals of the time series are not significantly different from zero (lag length $=28$ ).

The final ADL model after the crisis (Table 8) can be written as follows:

$$
\begin{aligned}
\overline{C O N_{-} A C_{t}} & =0.52 C O N_{-} A C_{t-1}+0.42 C O N_{-} A C_{t-4}-23.93 R I R_{-} A C_{t}- \\
& -0.43 R E E R_{-} A C_{t-2}-299.39 D 4_{t}
\end{aligned}
$$


Based on the results of the ADL model, it is clear that Latvian Consumption is not directly dependent on Income in the assessed period after the crisis since the variable representing income was not significant in the model. The author has rewritten the model in the form of an EC model:

$$
\begin{aligned}
\Delta \overline{C O N_{-} A C_{t}} & =0.4778 \Delta C O N_{-} A C_{t-1}+0.4778 \Delta C O N_{-} A C_{t-2}+ \\
& +0.4778 \Delta C O N_{-} A C_{t-3}-23.9281 \Delta R I R_{-} A C_{t}-23.9281 \Delta R I R_{-} A C_{t-1} \\
& -23.9281 \Delta R I R_{-} A C_{t-2}-23.9281 \Delta R I R_{-} A C_{t-3}+ \\
& +0.4127 \Delta R E E R_{-} A C_{t-2}+0.4127 \Delta R E E R_{-} A C_{t-3}+ \\
& +0.4778\left(C O N_{-} A C_{t-4}+50.0798 R I R_{-} A C_{t-4}-0.8638 R E E R_{-} A C_{t-4}\right)
\end{aligned}
$$

The EC model shows the speed of the system's convergence to reach its long-term equilibrium in the case of a deviation of the current state from its long-run relationship as measured by the parameter $\gamma(0.4778)$ and the long-term relationship between the variables as measured by the multipliers $\phi(50.0798)$ and $\delta(0.8638)$. The long-term relationship is expressed by the term $\mathrm{EC}$, which is given by the equation:

$$
E C_{t}=C O N_{-} A C_{t}+50.0798 R I R_{-} A C_{t}-0.8638 R E E R \_A C_{t}
$$

This result confirms the author's expectations based on Figure 8 and suggests that during the analysed period consumption was driven by existing quality of living and other macroeconomic variables, rather than by income.

\section{Public Finance Implications}

The findings of this study confirm that the "status quo bias" behavioural concept is applicable to a population based on macroeconomic data. This presents some possible implications for public finance. Contrary to the proponents of neoclassical economics, an agent in the economy tends to behave differently from a robot designed for making rational decisions; thus, in the presented case, people desire to maintain their level of consumption despite negative impacts of an economic crisis on their income. This observation could be applied in the process of defining public policy design in the case of another economic crisis and within the state budget formation process. Firstly, as the consumption would be higher than expected, revenue based on consumption taxes would be higher as well, thus there is a potential for more accurate budget construction and therefore an opportunity to enhance the efficiency of allocated resources. Secondly, such knowledge enables modification to construction and/or parameters of taxes directly 
linked to consumption. This may support government policy during an economic crisis or unfavourable business cycle and catalyse its measures and action steps intended to accelerate economic growth and public welfare.

\section{Conclusions}

The main objective of the paper was to provide an in-depth analysis of the status quo concept based on macroeconomic data. The recent global economic crisis has provided a valuable opportunity for analysing the concept and ensured that relevant and sufficient inputs for such academic research are available. First, the author selected appropriate datasets for the research, i.e., country and time series. Based on the criteria specified in the article, the author decided that Latvia is the most suitable country for the analysis. The behavioural concept was evaluated using an analysis of the relationship between Latvian Consumption and Income before and after the crisis. For this purpose, the author ran two co-integration analyses as well as constructed ADL models to evaluate the basis of the relationship between the time series. A statistically significant long-term relationship between the Latvian Consumption and Income has been found only before the crisis.

Therefore, it could be concluded that the long-term relationship between the respective time series was valid only until the economic crisis; afterwards, this co-integration relationship faded, suggesting a different trend of selected variables from the given reference point. The decrease in income in the period after the crisis is significantly different from the decrease in agents' consumption, which is lower due to their motivation to maintain the overall quality of living. Therefore, the results suggest that consumption after the crisis was primarily driven by past consumption, i.e., previously achieved welfare. Such results can be interpreted as verifying the status quo behavioural concept based on the macroeconomic data. This confirms evidence from experimental studies presented in the theoretical framework using real-world data.

These findings may be used during the state budget formation process or interventions in the area of consumption taxes in order to accelerate economic growth and public welfare, primarily after an economic crisis or during unfavourable business cycle. 


\section{Appendix}

\section{ADL model description}

The model evaluates the possibility of a long-term relationship based on stationarity of residuals of the following statistic regression model:

$$
y_{t}=\beta X_{t}+\alpha_{t}
$$

The time series are co-integrated if the residuals of the model consisting of non-stationary variables are stationary. In the case of alternative results, there is a risk that the relationship is driven by spurious regression. Identified co-integration relations will be further analysed using the Autoregressive Distributed Lag model - ADL (Hendry et al., 1984), e.g., the $\operatorname{ADL}(1,1)$ model has the following form:

$$
Y_{t}=c+\alpha_{1} Y_{t-1}+\beta_{1} X_{t}+\beta_{2} X_{t-1}+\alpha_{t} .
$$

Consequently, the so-called Error Correction Model (ECM) will be derived in order to distinguish between the short- and long-term relationship (Engle and Granger, 1987):

$$
\Delta Y_{t}=c+\beta_{1} \Delta X_{t}+\gamma\left(Y_{t-1}-\beta X_{t-1}\right)+\alpha_{t}
$$

where $\beta=\left(\beta_{1}+\beta_{2}\right) /\left(1-\alpha_{t}\right)$ and $\gamma=\alpha_{t}-1$. If the parameter $\gamma=0$, there is no co-integration between the time series (Arlt et al., 2001). In accordance with the tested behavioural concept, one-equation models will be used, in which the Consumption is always an endogenous variable, whereas all the other variables are considered to be of an exogenous nature (Arlt and Arltova, 2009).

\section{Static regression model before crisis}

\section{Dependent variable: CON_BC}

\begin{tabular}{l|c|c|c|c}
\hline Variable & Coefficient & Std. error & $t$-Statistic & Prob. \\
\hline $\boldsymbol{C}$ & 248.0311 & 235.871 & 1.0516 & 0.3004 \\
\hline INC_BC & 0.6329 & 0.0185 & 34.1313 & 0.0000 \\
\hline $\boldsymbol{R I R \_ B C}$ & 11.6463 & 5.3348 & 2.1831 & 0.0360 \\
\hline $\boldsymbol{R E E R \_ B C}$ & -3.9863 & 3.0158 & -1.3218 & 0.1951 \\
\hline Adj. $\boldsymbol{R}^{\mathbf{2}}$ & & & Durbin-Watson & 1.1807 \\
\hline
\end{tabular}

Source: own calculations 


\section{Static regression model after crisis}

\begin{tabular}{|c|c|c|c|c|}
\hline \multicolumn{5}{|c|}{ Dependent variable: CON_AC } \\
\hline Variable & Coefficient & Std. error & $t$-Statistic & Prob. \\
\hline C & $4,518.1990$ & $1,027.3360$ & 4.3980 & 0.0002 \\
\hline INC_AC & 0.5002 & 0.0422 & 11.8481 & 0.0000 \\
\hline$R I R \_A C$ & -39.8957 & 10.2024 & -3.9104 & 0.0008 \\
\hline REER_AC & -9.6345 & 4.6425 & -2.0753 & 0.0499 \\
\hline Adj. $R^{2}$ & \multicolumn{2}{|c|}{0.9075} & Durbin-Watson & 1.4825 \\
\hline
\end{tabular}

Source: own calculations

\section{References}

Arlt, J., Guba, M., Radkovský, Š., et al. (2001). Vliv vybraných faktorů na vývoj poptávky po penězích v letech 1994-2000. Politická ekonomie, 49(5), 635-657, https://doi.org/10.18267/j.polek.331

Arlt, J., Arltová, M. (2009). Ekonomické časové řady. Prague: Professional Publishing. ISBN 978-80-86946-85-6.

Breusch, T. S., Godfrey, L. G. (1986). Data Transformation Tests. Economic Journal, 96 (Supplement), 47-58, https://doi.org/10.2307/2232969

Cupalová, M. (2009). Dopady světové ekonomické krize na veřejné rozpočty v zemích EU a vývoj českých veřejných financí. Parlamentní institut. Available at: http://www.psp.cz/sqw/text/ orig2.sqw?idd $=58368$

Darnell, A. C. (1994). A Dictionary of Econometrics. Cheltenham: Edward Elgar Pub. ISBN 978-1852783891.

Dickey, D. A., Fuller, W. A. (1979). Distribution of Estimators for Autoregressive Time Series with a Unit Root. Journal of American Statistical Association, 74(366), 427-431, https://doi.org/10.2307/2286348

Engle, R. F., Granger, C. W. J. (1987). Cointegration and Error Correction Representation:

Estimation and Testing. Econometrica, 55(2), 251-276, https://doi.org/10.2307/1913236

Forbes (2009). The World's Hardest-Hit Economies [online]. [Retrieved 2009-07-08] Available at: https://www.forbes.com/2009/07/08/economics-iceland-ireland-business-beltwaycountries.html\#143e00331b77

Friedman, M. (1957). A Theory of the Consumption Function. Cambridge, MA: National Bureau of Economic Research. ISBN 0-691-04182-2.

Granger, C. W. J., Newbold, P. (1974). Spurious Regressions in Econometrics. Journal of Econometrics, 2(2), 111-120, https://doi.org/10.1016/0304-4076(74)90034-7 
Hendry, D. F., Pagan, A. R., Sargan, J. D. (1984). Chapter 18 Dynamic Specification, in Griliches, Z., Intriligator, M. D., eds., Handbook of Econometrics, Vol. II. Amsterdam: Elsevier B.V., pp. 1023-1100, https://doi.org/10.1016/s1573-4412(84)02010-9

Izák, V. (2011). Fiscal Policy: Intermediate Course. 3th ed. Praha: Oeconomica. ISBN 978-80-245-1786-5.

Jarque, C. M., Bera, A. K. (1980). Efficient Tests for Normality, Homoscedasticity and Serial Independence of Regression Residuals. Economics Letters, 6(3), 255-259, https://doi.org/10.1016/0165-1765(80)90024-5

Johnson, E. J., Goldstein, D. G. (2004). Defaults and Donation Decisions. Transplantation, 78(12), 1713-1716, https://doi.org/10.1097/01.tp.0000149788.10382.b2

Kahneman, D., Knetsch, J. L., Thaler, R. H. (1991). Anomalies: The Endowment Effect, Loss Aversion, and Status Quo Bias. Journal of Economic Perspectives, 5(1), 193-206, https://doi.org/10.1257/jep.5.1.193

Kempf, A., Ruenzi, S. (2005). Status Quo Bias and the Number of Alternatives: An Empirical Illustration from the Mutual Fund Industry. Centre for Financial Research (CFR). Cologne Working Paper No. 05-07, https://doi.org/10.2139/ssrn.820905

Latvian Government (2009). Par valsts un pašvaldību institūciju amatpersonu un darbinieku atlīdzību 2009.gadā.

Official Journal of Latvia (2010). Par valsts pārvaldes, civildienesta un atalgojuma sistēmas reformu un progresu atalgojuma samazināšanā valsts sektorā strādājošajiem. 2010.

Purfield, C., Rosenberg, C. B. (2010). Adjustment Under a Currency Peg: Estonia, Latvia and Lithuania During the Global Financial Crisis 2008-09. International Monetary Fund. Washington, D.C. Working Papers No. 2010/213, https://doi.org/10.5089/9781 455205448.001

Přehled vybraných makroekonomických ukazatelů zemí Evropské unie a dalších světových center a analýza webových "statistických" serverů ("Overview of Selected Macroeconomic Indicators of European Union Countries and Other World Centres and Analysis of "Statistical" Servers"). Praha, 2011

Samuelson, W., Zeckhauser, R. J. (1988). Status Quo Bias in Decision Making. Journal of Risk \& Uncertainty, 1(1), 7-59, https://doi.org/10.1007/bf00055564

Spurná, J. (2013). Souvislosti platební bilance a měnového kursu (analýza a komparace vybraných ekonomik) (Diplomová práce). Praha: Vysoká škola ekonomická v Praze.

U.S. Census Bureau (2004). X-12-ARIMA. Washington, DC: U.S. Census Bureau, U.S. Department of Commerce. 